Commercial Aspects of Gold Applications: From Materials

\section{Science to Chemical Science}

\author{
Dr Christopher W. Corti and Dr Richard J. \\ Holliday \\ International Technology, World Gold Council, London
}

A major aim of the GOLD 2003 conference is to promote new gold related science and technology with a view to developing new useful industrial applications for gold. Current industrial uses have provided a steady annual demand for gold of around 350-400 tonnes in recent years, the bulk of which is centred on electronics applications, with dental uses constituting the second largest application. However, there is good reason to believe that whilst gold will continue to play a major role in these sectors in the future, substantial growth of demand is not anticipated. Increased industrial demand for gold is only likely to come through the emergence of new applications, probably most significantly in five broad market sectors:

* Pollution and emission control technologies, including fuel cells.

* New uses for gold in advanced electronics, electrical systems and devices.

* Chemical processing of a range of bulk and speciality chemicals, using gold based catalysts.

* Advanced coatings exploiting the novel properties of gold, particularly in nanoparticulate form.

* New biomedical uses for gold including medical treatments, drugs, implants, sensors and devices.

There is cause for optimism that many new applications for gold could emerge in these sectors over the next decade and that this will lead to a substantial growth in demand for gold. It is clear that many of these new opportunities will be based on a chemical approach to synthesis of useful products rather than what has historically been a materials or mechanical approach. To turn this expectation into reality requires sustained support of $R \& D$ and a determination to exploit this new science and technology into viable commercial applications.

\section{Introduction}

The sub-title of the GOLD 2003 conference, 'New Industrial Applications for Gold', reflects a major aim of the conference, namely to promote new industrial ( \& medical) applications for gold. Basic research in appropriate areas is an essential first step towards identifying opportunities for new applications and using it to benefit mankind is essential if funding of gold related research and development is to continue. Work within World Gold Council is concerned with generating increased demand for gold through exploitation and commercialisation of science. To support this, it is helpful to consider the whole spectrum of gold science and technology and indicate those areas that it is believed hold some commercial promise. This analysis, set in the context of why so little gold is used currently in industrial applications compared to other precious metals, assists us in establishing what prospects there are for future growth in demand for gold. It is considered that the evolution of gold's industrial usage will go from one based essentially on materials science to one increasingly based on chemical science.

\section{Current Applications}

Many of the current applications for gold are based on its physical properties, although the corrosion resistance of bulk gold is also a major attribute. Table 1 below shows some of the main properties of gold compared to other metals. It can be seen that gold has a broadly beneficial combination of properties relating to its electrochemical potential, and electrical and thermal resistivity. However, as will be described later, it is the properties of gold on the nanoscale and its chemical properties that are considered increasingly important for its future uses.

These unique properties are exploited in a diverse range of industrial applications. For example, the Royal Bank Plaza building in Toronto, Canada, has 14,000 windows all coated with pure gold $(70,000 \mathrm{~g}$ of gold in total, worth over $\$ 3 / 4$ million dollars). This is enough to mint 50,000 Maple Leaf

Table 1

Selected Properties of Gold and Other Metals

\begin{tabular}{lccc} 
Metal & $\begin{array}{c}\text { Electrode } \\
\text { Potential (V) })\end{array}$ & $\begin{array}{c}\text { Electrical } \\
\text { Resistivity } \\
(\Omega \mathbf{c m})\end{array}$ & $\begin{array}{c}\text { Thermal } \\
\text { Conductivity } \\
\left(\mathbf{W m}^{-1} \mathbf{K}^{-1}\right)\end{array}$ \\
\hline Gold & +1.7 & 2.4 & 319 \\
\hline Platinum & +1.2 & 9.9 & 72 \\
\hline Silver & +0.8 & 1.6 & 428 \\
\hline Copper & +0.3 & 1.7 & 403 \\
\hline Aluminium & -1.7 & 2.7 & 238 \\
\hline
\end{tabular}




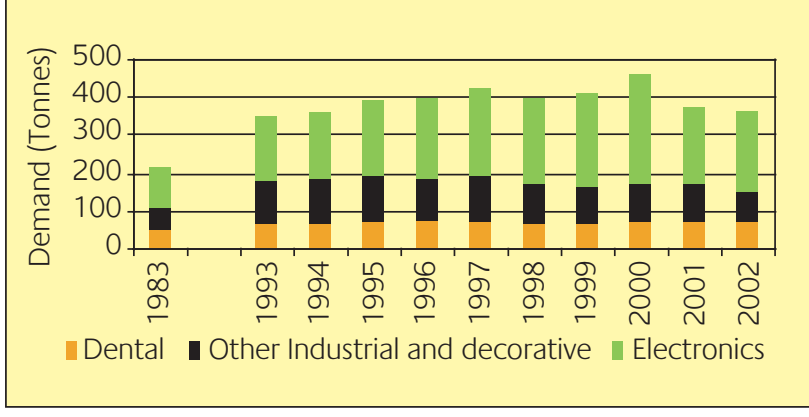

Figure 1

Industrial Demand for Gold (Source: Gold Survey 2003, GFMS)

coins. Here, the property of interest is optical reflectivity, particularly in the infra-red region of the spectrum. The gold reduces heating and ventilation costs inside the building, thereby making it's use cost effective.

If we look at current usage for gold, we can see that these applications have provided a steady annual demand for gold in industrial uses of around 350-400 tonnes, the bulk of which is centred on electronics applications, with dental as the second largest application, Fig 1.

Gold is used primarily as an electrical conductor in several ways (1). In fact, the last major new use for gold in industrial applications was gold bonding wire, introduced into the electronics industry around 30 years ago. However, with the advent of miniaturisation of electronic devices and the tendency to thrift on expensive materials, the growth in gold consumption has not mirrored that in electronics over the last few decades. Despite gold's technical superiority in these applications, increasingly, in the high volume, low-end applications such as consumer electronics, cheaper competing materials with poorer performance tend to dominate. This is notable in the market for connectors, where palladium competes primarily on price. Whilst gold will continue to play a major role in the future, for example in automotive electronics, where conditions are more aggressive, substantial growth of demand is not anticipated.

In terms of dental applications, gold is biocompatible and, along with its other attributes of corrosion resistance and mechanical properties, these have resulted in a long history of use (2). Today, gold continues to be used for crowns and bridgework, porcelain enamel onlays and inlays, mostly in cast form although electroforms are gaining in popularity. Most dental alloys are gold alloyed with palladium and/or platinum plus silver and other small additions. There are a myriad of alloys on the market, ranging from low to high gold contents (12 - 90\% gold). The choice of alloy selected tends to be price-driven and hence the relative price of gold and palladium influences choice.

We should also note that the countries with the largest dental gold markets are those where the state national
Table 2

Annual Industrial Demand for Precious Metals as a Percentage of Total Demand

\begin{tabular}{lccccc} 
& Gold & Silver & Platinum & Palladium \\
\hline Industrial \% & 12 & 66 & 49 & 94 \\
\hline Jewellery \% & 80 & 27 & 51 & 3 \\
\hline Other \% & 8 & 7 & - & 3 \\
\hline
\end{tabular}

health insurance schemes support the use of gold materials. Such support is coming under increasing budgetary pressures and this tends to favour the specification of lower gold-containing alloys. This, coupled with increasing competition from non-precious metal dental materials suggests that growth in future gold demand in this application will be limited.

Despite these applications in electronics and dental, when we look at the total industrial demand for gold, we see that industrial applications constitute only about $12 \%$ of overall annual demand (which is around 3000 tonnes for gold), Table 2. This is a conspicuously low figure compared with the other important precious metals. This comparison suggests that there is scope for increasing the industrial demand for gold. Based on what has previously been described, future increased demand for gold is only likely to come through the emergence of new applications.

\section{Emerging Applications}

At this stage, it is relevant to consider why there have been no new major applications for gold in decades. In fact, there have been a number of contributing factors to this situation. In industry there has been a perception that gold is expensive, which dates back to the high gold price in the early 1980s, and hence it is not considered likely to be an economic solution to industrial problems. In school, we are all taught that gold is the most noble of metals; it is incorruptible and is chemically inert. Research into gold has therefore been perceived as costly and not fruitful and so gold-based chemistry is comparatively underdeveloped. In the catalysis field, gold has been considered the odd metal in that it is not very catalytically active in contrast to other precious and transition metals. Thus new gold science has been slow to emerge and so new applications have also not emerged.

However, there are now encouraging signs of change. We are seeing a change in the Universities and industrial research centres. Gold chemistry and its related technologies are being investigated to good effect, and new areas are emerging, nanotechnology being a good example. Coupled with this, there has been a scientific breakthrough in the field 


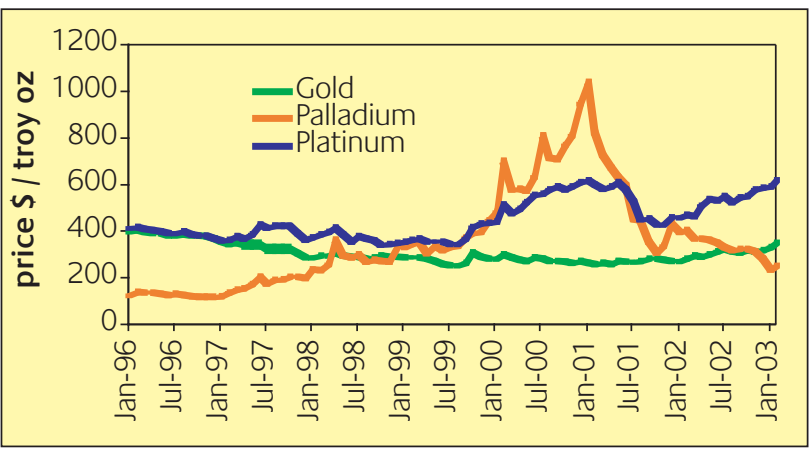

Figure 2

Precious metals prices 1996 - 2002

of gold catalysis, and gold chemistry is at last attracting the attention it deserves. From the gold industry's standpoint, there has been recognition of the importance of stimulating and exploiting gold science and technology.

There is also an improved recognition that gold is not expensive compared to the platinum group metals (PGMs), nor has its price varied widely as the PGMs costs have in recent years. Industrialists prefer stable prices, Fig 2 . This graph vividly illustrates the stability in gold price versus its main platinum group metal competitors. It is also relevant to note that gold supply is much more plentiful, by an order of magnitude, than that of the PGMs. Thus any significant new demand is unlikely to impact on gold price to any extent, unlike the PGMs. This is a powerful economic factor in the choice of technology.

Industrial interest in certain areas of gold science also appears to be increasing, illustrated by considering gold catalysis intellectual property as an example. If we assume that the number of patents granted is a measure of commercial interest and activity, then we can see there is an encouraging future for gold catalysts in industry. It is particularly interesting to note the large number of major companies who have obtained patents on gold catalyst technology. Many of these are 'household' names with a history of innovation and new technology development. It is considered this interest is real, with several companies having pilot plants in operation.

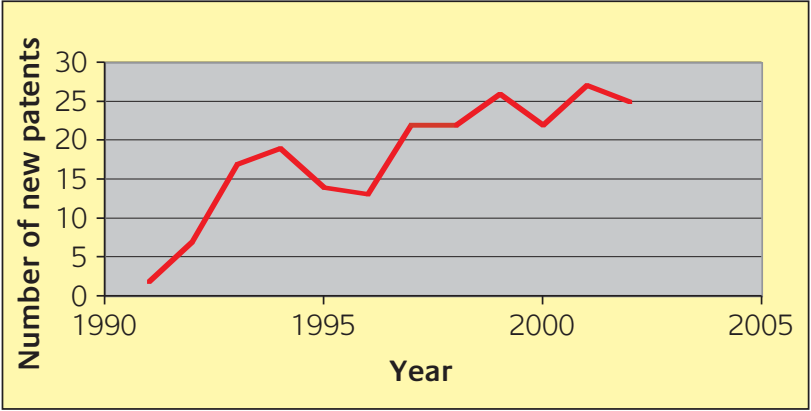

Figure 3

Number of patent applications based on catalysis by gold (1991-2002)
Of the new applications for gold that are beginning to emerge, many are based on a chemical approach to synthesis of useful products rather than what has historically been a materials or mechanical approach. It is worthwhile reviewing some of these new applications.

Broadly, it is considered that many of these applications are covered by five market sectors. These sectors are:

- Pollution and emission control technologies, including fuel cells.

- New uses for gold in advanced electronics, electrical systems and devices.

- Chemical processing of a range of bulk and speciality chemicals, using gold based catalysts.

- Advanced coatings exploiting the novel properties of gold, particularly in nanoparticulate form.

- New biomedical uses for gold including medical treatments, drugs, implants, sensors and devices.

\section{Pollution Control}

Perhaps the greatest commercial opportunity for gold based catalysts lies in a number of potential uses within the automotive industry. With over 50 million light vehicles produced per year, this is a huge market for the catalyst industry. It is fair to say that catalyst systems based on the platinum group metals perform the task of emission control very well and are able to meet current legislative emission targets. Much of the present research focused on this type of technology is based on cost reduction through thrifting of precious metal content. Whilst the price of gold compares very favourably with platinum, it is the ability of gold as a component within a three-way catalyst to withstand the elevated temperatures required that is in doubt. However, for those keen to see the potential for gold investigated, it is very helpful and encouraging to see that two market trends are moving in a favourable direction. Firstly, there is the dramatic growth in popularity in diesel engines. About $40 \%$ of vehicles built in Europe are now powered by diesel engines and catalytic converter systems for diesel engines tend to operate at lower temperatures than petrol engines. This lower temperature could be critical in providing conditions of stability for gold nanoparticles. Secondly, for gasoline engines there is now increasing focus on the challenge of improving low cold start performance of catalytic systems. i.e. controlling those emissions created when a vehicle is first turned on in the morning, before the current system is operating at optimum performance. The well-known low temperature activity of gold catalysts could have a role to play in this application. Clearly, neither of these applications will be achieved in the short term and there are significant engineering challenges to be overcome. A recent patent application by Toyota claiming stability of gold catalysts at $800^{\circ} \mathrm{C}$, suggests that the necessary work is underway (3). 
Table 3

Potential areas within automotive systems for using nanoparticulate gold catalysts

\begin{tabular}{|c|c|c|c|c|c|}
\hline $\begin{array}{c}\text { Automotive } \\
\text { Power } \\
\text { Source }\end{array}$ & $\begin{array}{l}\text { Potential } \\
\text { Application for } \\
\text { Gold Based } \\
\text { Catalysts }\end{array}$ & Reaction(s) & $\begin{array}{l}\text { Main Characteristics of } \\
\text { Supported Gold } \\
\text { Nanoparticulate } \\
\text { Catalyst }\end{array}$ & $\begin{array}{l}\text { Remaining } \\
\text { Technical } \\
\text { Barriers }\end{array}$ & $\begin{array}{l}\text { Indicative } \\
\text { Patent } \\
\text { Applications } \\
\text { (Reference) }\end{array}$ \\
\hline \multirow{4}{*}{ Fuel Cell } & \multirow{3}{*}{$\begin{array}{c}\text { Fuel processing } \\
\text { systems for clean } \\
\mathrm{H}_{2} \text { production }\end{array}$} & $\begin{array}{l}\text { Water gas shift reaction } \\
\text { for } \mathrm{H}_{2} \text { production }\end{array}$ & $\begin{array}{l}\text { High activity at low } \\
\text { temperatures }\end{array}$ & Durability unclear & - \\
\hline & & $\begin{array}{l}\text { Preferential oxidation } \\
\text { of } \mathrm{CO} \text { for } \mathrm{H}_{2} \text { clean up }\end{array}$ & $\begin{array}{l}\text { High activity at low } \\
\text { temperatures }\end{array}$ & Durability unclear & $5,6,7$ \\
\hline & & $\begin{array}{l}\text { Methanol decomposition } \\
\text { for } \mathrm{H}_{2} \text { production }\end{array}$ & High activity & $\begin{array}{l}\text { Limited published } \\
\text { studies to date }\end{array}$ & - \\
\hline & Fuel cell catalyst & $\begin{array}{l}\text { Oxidative removal of } \\
\qquad \mathrm{CO} \text { from } \mathrm{H}_{2}\end{array}$ & $\begin{array}{l}\text { Improvement in electrical } \\
\text { conductivity }\end{array}$ & $\begin{array}{l}\text { Limited published } \\
\text { studies to date }\end{array}$ & 8 \\
\hline Diesel Engine & $\begin{array}{l}\text { Component of TWC } \\
\text { for diesel engine } \\
\text { emission control }\end{array}$ & $\begin{array}{c}\mathrm{CO} \text { and } \mathrm{HC} \\
\text { combustion and } \\
\text { NOx reduction } \mathrm{HC}\end{array}$ & $\begin{array}{l}\text { Low temperature activity } \\
\text { (and high for NOx reduction) }\end{array}$ & $\begin{array}{l}\text { Thermal durability } \\
\text { and } \mathrm{SO}_{2} \text { poisoning }\end{array}$ & 3,9.10, \\
\hline Petrol Engine & $\begin{array}{l}\text { Low light off catalyst } \\
\text { for petrol engine }\end{array}$ & $\begin{array}{l}\mathrm{CO} \text { and } \mathrm{HC} \\
\text { combustion }\end{array}$ & Low temperature activity & $\begin{array}{l}\text { Thermal durability } \\
\text { and } \mathrm{SO}_{2} \text { poisoning }\end{array}$ & 9,10 \\
\hline
\end{tabular}

If gasoline and diesel engines are the current automotive power source of choice, then fuel cells are claimed to be the future based on their environmental friendliness. With hydrogen widely considered to be the likely long-term fuel choice for vehicles, there is probably a need for a number of new commercial catalysts in this system for hydrogen generation, hydrogen purification and of course within the fuel cell itself for catalysing the hydrogen plus oxygen reaction, the basis of fuel cell energy generation. It is believed that there are significant opportunities for gold catalysts in this industry (4), Table 3.

Taking the growth of the platinum metals usage in automotive pollution control as an example, it is clear how the growth in a new application can stimulate demand for a metal. Since the adoption of autocatalyst technology by the major automotive manufacturers approximately twenty years ago, around 250 tonnes of annual PGM demand has been created, Fig 4. A similar growth is possible for gold, if it can be successfully applied.

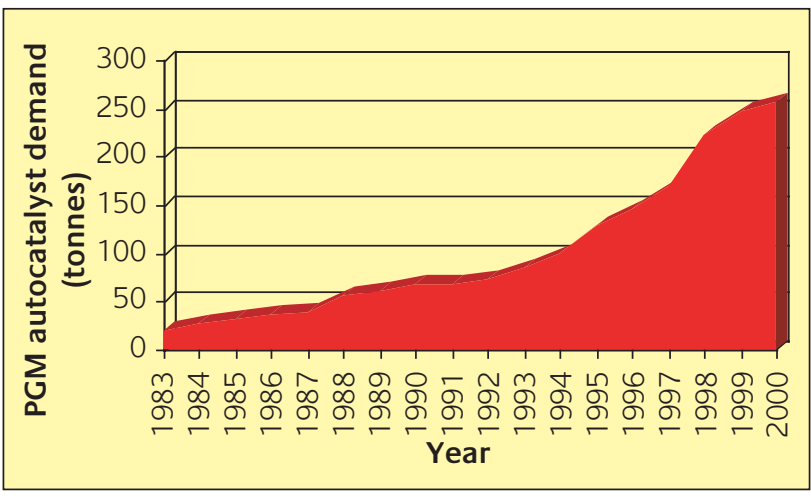

Figure 4

Annual demand for PGMs in autocatalysts (Source: Johnson Matthey, Platinum 2002)
As well as control of automotive emissions, there are a number of potential commercial applications in other areas of pollution control. Control of mercury, which has been linked to Alzheimer's disease and autism, is expected to be the subject of legislation in 2004 by the Environmental Protection Agency in the US. They are expected to impose limits on mercury emissions from coal-fired boilers in the utility industry. Approaches to control these emissions include the oxidation of mercury via gold catalysts and an alternative metallurgical approach of using gold-coated carbon, which effectively adsorbs the mercury vapour and is later recycled.

The scientific literature is now showing that decomposition of ozone is a reaction that gold catalyses effectively (11-12). Control of ozone which can be emitted by equipment such as photocopiers and laser printers and which can be a contributor to the formation of smog, is a significant commercial application. For example, the car manufacturer Volvo has its S80 model's radiator coated with a base metal catalyst that breaks down around $80 \%$ of ozone passing over it.

Dioxin decomposition is an application where a low temperature catalyst might reduce the need for thermal incineration and its associated high energy costs (13). The ability of gold to oxidise CO and remove NOx compounds offers scope for air quality improvement and control of malodours, be they in buildings, transport or other applications. The scope here for commercial applications is very large.

\section{Future Electronics}

We are currently in the relatively early days of the science of self-assembly nanowires and the applications envisaged are still the subject of conjecture. However, what is clear is that future electronic devices are likely to require fabrication around the 
nanoscale and that gold is an ideal material in this respect. A clear demonstration of this interest is that of the 65 papers presented at the recent British Royal Society of Chemistry meeting on 'Nanoparticle Assemblies', approximately 50\% were focused on the use of gold nanoparticles (14).

Future demand for gold could potentially benefit from the predicted rapid rise in use of high temperature superconducting tapes, sales of which it is estimated in some quarters will reach $€ 1.6$ billion by 2010. Applications include new electronics, power transmission and magnetic resonance imaging or MRI scans. This type of application requires extremely high magnetic fields only obtainable through superconducting properties. Although this technology is young, a thin gold coating on these superconducting tapes may be required. If indeed this is the case, then this application could lead to a significant tonnage of gold usage. Recent work also suggests that new voltaic devices based on thin gold films on $\mathrm{TiO}_{2}$, in conjunction with a photoreceptor, could make effective solar panels (saving fabrication costs by removing the need for silicon). Work is now focusing on increasing efficiency levels (15).

All of these three technologies rely on gold's electron conducting properties but gold is also of course an excellent optical reflector of light and its compounds exhibit photo luminescent properties and this puts the metal in good shape for future applications in optical electronics or optronics.

\section{Chemical Processing}

The use of gold catalysts in chemical processing offers very real potential for an important medium term use for gold. The use of gold-palladium catalysts in the production of vinyl acetate monomer is well established and a number of other reactions are now the focus of intense study, with gold-based catalysts potentially able to improve the economics of existing processes. For example, current commercial production of propene oxide (used extensively in the production of polyurethanes) is often based on a chlorohydrin process. Gold based catalysts might offer the opportunity to eliminate chlorine from the production process, as well as reduce water consumption and salt byproducts. Patents for propene oxide production using gold catalysts are now appearing $(16,17)$. An exciting prospect for gold catalysts, therefore, is the possibility of them opening up entirely new routes for chemical synthesis, as Hashmi has suggested at the Catalytic Gold conference in Cape Town.

Another reaction for which gold catalysts are attracting attention is the local generation of hydrogen peroxide. Global sales of hydrogen peroxide are rising at a rate of about $10 \%$ per year, due in part to it being viewed as an environmentally friendly alternative to chlorine (18). Currently, hydrogen peroxide is produced on a large scale (over 20k tonnes/annum) and involves several hazardous steps. Transportation from point of manufacture to point of use is expensive and there is a definite market need to develop a safe, modular process that can be operated cost effectively at the point of use. There is evidence emerging in the literature and patent applications that gold-based catalysts might be applied effectively for this purpose $(19,20)$. There is an interesting link in this potential application to the gold mining industry where peroxide is used to destroy cyanide waste. Transport of peroxide to remote mining sites is expensive and local on-site production would be of major benefit.

\section{Advanced Coatings}

Colloidal gold has long been the basis of decorative effects in glass and on tableware in the form of purple and pink enamel colours. Nanoparticulate gold is now being used to produce conventional gold decoration on tableware via the use of decals; this overcomes a longstanding technical problem with the use of conventional 'liquid gold' formulations. Recently, Nippon Paint have introduced a new polymerstabilised, gold nanoparticle-containing paint. This has novel dynamic optical effects, changing colour depending on the external lighting conditions (21).

It is interesting to consider other applications for these types of decorative effects. A similar type of technology could be envisaged as an anti-counterfeiting measure for security documents and bank notes. We live in a world where security officials are constantly trying to keep one step ahead of the criminal world, by introducing new technologies to prevent counterfeiting. Control of colour through advanced inks is one technique that can be used and it is reasonable to assume that carefully controlled gold nanoparticles could be incorporated into inks providing novel and unique optical effects irreproducible by those without the careful preparative techniques needed to make the inks. It would be interesting if the original form of money, gold, became a

Table 4

Current and emerging uses of gold in biomedical applications

\begin{tabular}{l|c|c|c} 
& $\begin{array}{c}\text { Bulk gold } \\
\text { alloys }\end{array}$ & $\begin{array}{c}\text { Gold } \\
\text { Nanotechnology }\end{array}$ & $\begin{array}{c}\text { Gold } \\
\text { Compounds }\end{array}$ \\
\hline Dental Alloys & $\mathrm{C}$ & & \\
\hline $\begin{array}{l}\text { Prosthesis / } \\
\text { implants }\end{array}$ & $\mathrm{C}$ & & \\
\hline Stents & $\mathrm{C}$ & & \\
\hline Sensors / & & $\mathrm{C}$ & \\
Labelling & & $\mathrm{P}$ & \\
\hline Drug Delivery & $\mathrm{E}$ & & $\mathrm{C}$ \\
\hline $\begin{array}{l}\text { Arthritis } \\
\text { Treatment }\end{array}$ & & & \\
\hline $\begin{array}{l}\text { Cancer } \\
\text { Treatment }\end{array}$ & & $\mathrm{P}$ & $\mathrm{E}$ \\
\hline Anti-bacterial & $\mathrm{P}$ & $\mathrm{P}$ & $\mathrm{P}$ \\
\hline
\end{tabular}

C-Current Application E-Emerging Application P-Possible Application 
component of high value bank notes to endorse their authenticity and validity.

Some interesting results from a recent World Gold Council GROW project indicate a possible new use for gold coatings might emerge (22). In this project it was found that a stainless steel coupon that had been exposed to $\mathrm{E}$ coli bacteria still had surviving viable bacteria remaining on its surface after 3 months at $4^{\circ} \mathrm{C}$. This contrasted with coupons electroplated with gold where no viable bacteria are found on the gold surface after a similar period. Silver is a well established anti-bacterial agent and there is a growing body of evidence that suggests gold could well be used in this way. As well as bulk gold, nano-particulate gold and gold compounds are showing anti-bacterial properties. This property opens up new commercial opportunities.

\section{Biomedical Applications}

The range of current and potential future applications for gold in the biomedical sector are highlighted below, classified by the form in which the gold is employed (bulk metal, nanoparticles, or compounds), Table 4. As well as the current use of gold in dental alloys, the bulk properties of gold are also used in inner ear implants and coatings for stents (the opacity of gold to $x$ rays helping surgeons to position the stent correctly). Gold also plays a role in targeted drug delivery through the "pharmacy on a chip' concept, where gold-coated microcapsules of drugs are controllably released intravenously into the body. This novel technology now being commercialised came out of research at MIT, USA. The previously described potential anti-bacterial effects might find application in coatings for catheters and wound dressing materials.

For gold nanotechnology, current applications in sensing and labelling (pregnancy testing kits are based on gold colloids) are being joined by emerging applications in the targeted destruction of cancer cells. Gold compounds already find use in drugs related to the treatment of arthritis and work is now emerging suggesting gold compounds can be effective in the treatments of some types of cancer.

\section{Exploitation of New Technology}

Some of these potential applications will emerge in the coming years, whereas others might not. However, certain actions can be taken to encourage more of these applications to be exploited and there are 4 main elements to a successful strategy for encouraging exploitation:

1. Most importantly, there is the need for sustained investment in gold R \& D to ensure new gold science \& technology is discovered and developed.

2. Secondly, this science cannot be usefully exploited if it remains unknown to those with the means to help commercialise it. So, communicating these new discoveries and developments to industry is vital. It is a prime reason for organising the GOLD 2003 conference.

3. There is a need to obtain a commitment from industry to exploit the technology, should it prove viable. This means actually making the technical and economic "case for gold' in order to promote the opportunity it offers.

4. Finally, harnessing all these elements, there is a need for an industry 'champion' for gold. This is the role of World Gold Council.

Encouragingly, many of these elements are now in place. For example, to ensure new gold science emerges, World Gold Council has initiated a programme of support for $R \& D$, known by its acronym, GROW [Gold Research Opportunities Worldwide]. In the 2 years since it commenced, 14 projects have been initiated in 9 countries. Many of these have strong industrial partners, increasing the likelihood of commercialisation of the results of the work. Several of these projects centre around gold catalyst applications such as fuel cells, but they also embrace nanomaterials, biomedical and materials projects.

With strong links to current and potential end-users of gold, World Gold Council can also act as a matchmaker between those with the ideas and new science and those with the means and desire to exploit them. For example, World Gold Council has facilitated collaboration between industry and academic partners in the field of gold catalysis for specific applications.

This can also be helpful when making applications for external research funding where an industrial collaborator or partner is a requirement of the selection process. There are some large funds of money available for researchers in gold related science. A \$5 million research budget for gold and silver catalysis was included in the recent US Energy Policy (H.R. 6) act is a prime example. President Bush also announced an additional $\$ 1.7$ billion for hydrogen energy programmes through the Department of Energy early 2003. Similar funding opportunities exist in other countries too, for example the Auricat programme funded from the European Union budget.

At the Catalytic Gold conference in Cape Town in 2001, it was suggested that a gold reference catalyst or catalysts should be made widely available to researchers to enable them to benchmark their own research and enable comparison with the work of other laboratories. In much the same way, platinum based reference catalysts were made available in the 1970's (and indeed still are). Based on this suggestion, World Gold Council commissioned a range of gold reference catalysts from Sud Chemie in Japan in 2002, under the guidance of Dr Haruta at AIST, Japan. Characterisation has been performed by Dr Tsubota also at AIST. The availability of the reference catalysts enables researchers to benchmark their own experimental results and it is believed that this should support the development and application of gold catalysts. A fourth reference catalyst (1\%Au on carbon) is also now available, having been prepared by Prof Michele Rossi of the University of Milan. Over 100 
samples of reference catalyst have been supplied so far to many universities and industrial companies, including Johnson Matthey, Engelhard, 3M, Dow Chemicals and Shell Chemicals.

As indicated earlier, communication of advances in science and its possible applications to industry is a key task. World Gold Council seeks to facilitate this objective in a number of ways including publication of Gold Bulletin (the highly-cited scientific journal) and Catgold News (keeping the gold catalysts community up to date with developments).

The searchable technical database of gold-related publications and patents on the Council's website went live in August 2002 and quickly attained 50,000 visits per month; it is updated on a quarterly basis with about 500 items per quarter.

In making the case for gold within specific end-user applications, World Gold Council also presents papers at targeted conferences and meets with key players in industry to create awareness and focus interest (e.g. 23,24).

Research is, by its very nature, an expensive undertaking and industry initiatives and wider funding for gold-based research is therefore vital. It is encouraging that other initiatives have been taken up to develop and exploit gold technology.

Project AuTEK in South Africa is a gold mining companyled project centred on Mintek R \& D laboratories to develop and commercialise new gold technologies. This project is multidisciplinary, encompassing work on applications for gold catalysts, metallurgy and nanotechnology.

The European Union has sponsored a programme in Europe on gold catalysis worth $€ 1.5$ million for a consortium of 8 universities and 4 industrial companies and World Gold Council. An initiative in Canada is under consideration, which will emulate Project AuTEK and involve North American gold mining companies and Canadian government support. These are signs of significant change in the gold industry.

\section{Conclusions}

In conclusion it is believed that there is cause for great optimism that many new applications for gold could emerge over the next decade and that this will lead to a substantial growth in demand for gold. It is clear that many of these new opportunities will be based on the new emerging chemicalbased sciences in place of the materials-based sciences of the current applications.

To turn this expectation into reality requires sustained support of $R \& D$ and a determination to exploit this new science and technology into viable commercial applications. In achieving this, it should be recognised that both industry and academia bears a responsibility to make the technoeconomic case for gold.

\section{References}

1 P. Goodman, Gold Bull., 2002, 35, 21

2 H. Knosp, C.W. Corti and R.J. Holliday, Gold Bull., 2003, 36, 59

3 Catalyst for Purifying an Exhaust Gas, European Patent Application, EP1043059, Toyota, 2000

4 D. Cameron, D.T. Thompson and R.J. Holliday, Journal of Power Sources, 2003, 118 298-303

5 Process for the Catalytic Oxidation of Carbon Monoxide and/or Methanol, European Patent Application, EP1209121, Haldor Topsoe, 2002

6 Catalyst and Process for Removing Carbon Monoxide from a Reformate Gas, US Patent Application, US20030012719, OMG AG, 2002

7 Production of Hydrogen Containing Gas, Japanese Patent, JP2153801, Mitsubishi, 1990

8 Electrode Catalyst for Fuel Cells, Japanese Patent Application, JP305001, Matsushita Electric Ind. Co., 2002

9 Catalyst Having a Zirconium Oxide and/or Cerium Oxide Support and Containing Gold and Transition Metal Oxide, US Patent 5895772 , Anglo American, 1999

10 Oxidation Catalyst Comprising Gold and Method of Oxidation, US Patent 6086835, Anglo American, 2000

11 Z. Hao, D. Cheng, Y. Guo and Y. Liang, Applied Catalysis, B: Environmental, 2001, 33(3), 217

12 P.M. Konova, A.I. Naydenov and D.R. Mehandjiev, Bulgarian Chemical Communications, 2002, 34(3/4), 437

13 O. Kajikawa, X-S. Wang, T. Tabata, and O. Okada, Organohalogen Compounds, 1999, 40, 581

14 D.T. Thompson, Private Communication, 2003

15 Re-gen magazine, April, 2003

16 Epoxidation of olefins using molecular oxygen and hydrogen involves catalyst comprising gold on support material, Patent Application W0200158887, Bayer AG, 2001

17 Catalyst for the production of epoxide comprises carrier containing oxide of titanium and/or zirconium, and gold fine particles fixed on the carrier, Patent Application US2001020105, Nippon Shokubai, 2001

18 Local and In-situ Generation of Hydrogen Peroxide: a Position Paper, The Institute of Applied Catalysis, UK, www.iac.org.uk

19 P. Landon, P.J. Collier, A.J. Papworth, C.J. Kiely and G.J. Hutchings, Chem. Commun., 2002, 2058

20 Process for producing hydrogen peroxide, Patent Application W002064500, Arco, 2002

21 T. Kobayashi, Nippon Paint Co. Ltd, Private communication, 2002

22 World Gold Council GROW Project RP 02 / 01

23 D.T. Thompson, C.W. Corti and R.J. Holliday, Automotive and Transportation Technology Congress, Paris, July, 2002 Paper 2002-012148

24 D.T. Thompson, C.W. Corti and R.J. Holliday, 35th Annual IICIT Connector and Interconnection Technology Symposium, Orlando USA, October, 2002, Paper 5 